\title{
HUBUNGAN PERSEPSI TERHADAP METODE PEMBELAJARAN DARING DENGAN MOTIVASI BELAJAR MAHASISWA PROGRAM STUDI SISTEM INFORMASI-UKSW
}

\author{
Prisilia Tehupuring ${ }^{1}$, Adriyanto J. Gundo ${ }^{2}$ \\ ${ }^{1,2}$ Universitas Kristen Satya Wacana Salatiga, Indonesia \\ *Corresponding Author: @ $702015027 @$ student.uksw.edu
}

\begin{tabular}{l} 
Info Artikel \\
\hline Sejarah Artikel: \\
Diterima: $02 / 12 / 2021$ \\
Direvisi : 18/12/2021 \\
Disetujui: $21 / 12 / 2021$ \\
\hline Keywords: \\
Learning motivation, \\
Online learning, Covid-19 \\
\hline
\end{tabular}

Kata Kunci:

Motivasi belajar,

Pembelajaran daring,

Covid-19

\begin{abstract}
The purpose of this study is to knowing and explaining the influence of the SWCU Salatiga information system student's perception of online learning methods on learning motivation during the Covid-19 pandemic. This type of research is descriptive quantitative. The research subjects used were Satya Wacana Christian University SI (Information System) active students, especially the 2019 and 2020 batches. The data collection technique of this research uses a questionnaire through the Google-Form media. The data that has been collected is then analyzed using univariate analysis techniques and bivariate analysis through the help of SPPS Version 20.0. The result of the study is that there is a relationship between student's perceptions and learning motivation towards the online learning method of the 2019 and 2020 SWCU Information Systems Study Program during the Covid-19 pandemic.
\end{abstract}

\begin{abstract}
Abstrak. Tujuan penelitian ini untuk mengetahui dan menjelaskan pengaruh persepsi mahasiswa sistem informasi Universitas Kristen Satya Wacana Salatiga Salatiga tentang metode pembelajaran daring terhadap motivasi belajar di masa pandemi Covid-19. Tipe penelitian ini adalah kuantitatif deskriptif. Subjek penelitian yang digunakan adalah mahasiswa aktif SI (Sistem Informasi) UKSW, khususnya angkatan 2019 dan 2020. Teknik pengumpulan data penelitian ini menggunakan kuisioner melalui media Google-Form. Data yang telah terkumpul kemudian dianalisis menggunakan Teknik analisis univariat dan analisis bivariat melalui bantuan SPPS Versi 20.0. Hasil penelitian yaitu bahwa terdapat hubungan antar persepsi dan motivasi belajar mahasiswa terhadap metode pembelajaran daring Program Studi Sistem Informasi UKSW angkatan 2019 dan 2020 di masa pandemi Covid-19.
\end{abstract}

How to Cite: Tehupuring, P., \& Gundo, A. J. (2022). HUBUNGAN PERSEPSI TERHADAP METODE PEMBELAJARAN DARING DENGAN MOTIVASI BELAJAR MAHASISWA PROGRAM STUDI SISTEM INFORMASI-UKSW. Prima Magistra: Jurnal Ilmiah Kependidikan, 3(1), 71-84. https://doi.org/10.37478/jpm.v3i1.1403

Alamat korespondensi:

Universitas Kristen Satya Wacana. Jalan Diponegoro 52-60 Salatiga, Kabupaten Semarang, Jawa Tengah

@702015027@student.uksw.edu

\section{Penerbit:}

Program Studi PGSD Universitas Flores. $\otimes$ primagistrauniflor@gmail.com 
Prisilia Tehupuring , Adriyanto J. Gundo

Hubungan Persepsi terhadap Metode Pembelajaran Daring dengan Motivasi Belajar Mahasiswa Program Studi Sistem Informasi-UKSW

Prima Magistra: Jurnal Ilmiah Kependidikan Volume 3, Nomor 1, Januari 2022, hal 71-84

\section{PENDAHULUAN}

Covid-19 yang saat ini terjadi hampir di setiap negara khususnya di Indonesia, menjadi salah satu permasalahan yang krisis dalam dunia kesehatan bahkan hidup bermasyarakat dan bernegara dalam skala Internasional. Akibat dari fenomena ini berimbas kepada setiap sektor termasuk sektor di bidang Pendidikan. Sebagai upaya dalam menghadapi krisis global ini maka pemerintah Indonesia memberikan kebijakan untuk melakukan segala aktivitas dari rumah atau work from home (WFH) dengan menggunakan internet. Kebijakan tersebut dikeluarkan pemerintah untuk memutuskan mata rantai penyebaran Covid-19.

Universitas Kristen Satya Wacana (UKSW) Salatiga sebagai sektor yang bergerak dibidang Pendidikan juga mengeluarkan kebijakan yang serupa untuk mendukung kebijakan pemerintah dalam memutus atau menghentikan penyebaran wabah Covid-19 dengan memberlakukan pembelajaran jarak jauh (PJJ) sejak 16 Maret 2020 dan selanjutnya menyesuaikan dengan kebijakan-kebijakan dari pemerintah yang hingga kini masih dilanjutkan dengan WFH sesuai dengan PPKM Level 4 yang diberlakukan hingga 09 Agustus 2021 untuk wilayah se-Jawa Bali. Upaya yang dilakukan tersebut adalah dengan tetap mengaktifkan metode pembelajaran daring.

Metode pembelajaran ini dilakukan sebagai bentuk menjaga dan menjamin kualitas atau mutu Pendidikan agar peserta didik tidak tertinggal jauh. Selain itu juga, mendukung kebijakan pelaksanaan physical distancing. Hal ini sejalan dengan pendapat Muhali (2019) yang menyatakan bahwa melalui metode pembelajaran kualitas pembelajaran jauh lebih terarah. Karena pembelajaran dengan metode seperti ini mengarahkan peserta didik untuk dapat berinovasi dan berpikir kritis serta sesuai dengan keterampilan Abad 21. Perlu diketahui dalam menggunakan metode ini banyak komponen-komponen yang perlu dipersiapkan selama pembelajaran berlangsung seperti platform teknologi yang dapat digunakan tanpa adanya batasan waktu dan tempat (Handarini \& Wulandari, 2020).
Raza et al (2021) serta Paais \& Andreas (2021) juga menyatakan bahwa untuk menunjang dan meningkatkan pembelajaran yang efektif dan efisien dalam perencanaan, pelaksanaan sangat dibutuhkan evaluasi atau tindak lanjut selama masa pandemi. Oleh karena itu, guru perlu menyesuaikan dengan media atau alat yang akan dipilih sebagai media bantu dalam menyalurkan materi. Sehingga dalam menunjang proses itu maka media yang dapat digunakan sebagai pendukung pembelajaran selama masa pandemi adalah google classroom, google meet, zoom meeting, Microsoft team lain sebagainya. Bukan hanya metode belajar saja yang mengalami perubahan akan tetapi proses belajar mahasiswa pun mengalami perubahan yang cukup drastis awalnya dengan metode tatap muka dalam kelas menjadi metode PJJ/daring. Perubahan ini tentu memberikan pengaruh terhadap motivasi belajar mahasiswa dan sekaligus memberikan adaptasi baru bagi mahasiswa program studi Sistem Informasi yang proses belajarnya tidak hanya berpatokan pada materi tetapi juga latihan/praktik. Menurut penelitian yang dilakukan oleh Tantri (2018) terhadap kehadiran sosial dalam pembelajaran daring dilihat dari sudut pandang pendidikan terbuka dan jarak jauh mendapatkan hasil bahwa pembelajaan secara daring memberikan dampak yang positif terhadap proses belajar dan setiap aspek pembelajaran.

Sebagai bentuk kontribusi pemerintah dalam mendukung pelaksanaan pembelajaran daring, pemerintah turut andil dalam memberikan keringanan pemberian tugas dan bantuan paket data bulanan dari Kemendikbud. Hal ini jelas membantu khususnya mahasiswa dalam melakukan proses belajar mengajar, namun tidak serta merta dapat memperlancar interaksi dan kualitas dari hasil belajar mengajar. Hal ini dikaitkan dengan motivasi belajar mahasiswa yang dipengaruhi oleh pembelajaran daring saat ini. Penelitian Denni (2020) yang dilakukan terhadap mahasiswa STMB MULTI SMART Medan menyatakan bahwa mahasiswa menyatakan "tidak setuju" dengan kebijakan kuliah yang diganti dengan kuliah daring selama masa pandemi 
sebanyak $72,2 \%$. Dengan jumlah presentase yang cukup besar ini menunjukan bahwa proses belajar yang diganti kepada pembelajaran daring ini akan sangat berpengaruh terhadap motivasi belajar mahasiswa.

Dalam penelitian yang dilakukan Maulah et al (2020) tentang persepsi mahasiswa dengan sasaran penelitian mahasiswa biologi Universitas di Kabupaten Jember terhadap perkuliahan daring sebagai sarana pembelajaran selama pandemi dari jumlah mahasiswa sebanyak 50, hasil penelitian menunjukan sebagian besar mahasiswa menyukai media pembelajaran whatssap yang lebih efektif sebanyak $47 \%$, komunikasi dua arah (70\%), gaya belajar (64 $\%)$ namum masih ada mahasiswa yang menyatakan bahwa metode pembelajaran daring masih belum cukup untuk menunjang pembelajaran daring hal ini dipengaruhi oleh berbagai faktor lainnya.

Motivasi belajar adalah sebuah kontruksi teoritis yang dibangun untuk memberikan arah, inisiasi, intensitas, ketekunan, perilaku, serta dorongan terhadap tujuan yang ingin dicapai serta mampu menimbulkan ketekunan dalam kegiatan pembelajaran dan menjamin keberlangsungan dari aktivitas belajar (Andriani \& Rasto, 2019). Dalam penelitian Dewi (2021) menjelaskan bahwa motivasi interal memiliki pernan yang besar pada saat pembelajaran dilakukan dalam jaringan atau pembelajaran jarak jauh hal ini dikarenakan dalam proses belajar jarak jauh ini membatasi perjumpaan dengan dosen sehingga penilaian pembelajaran dalam bentuk tes dan ujian menjadi berkurang. Di sisi lain besar atau rendahnya motivasi belajar yang dimiliki oleh mahasiswa dapat dipengaruhi oleh keadaan dan kondisi mahasiswa juga dengan kesiapan mahasiswa untuk beradaptasi dengan metode pembelajaran yang baru. Motivasi belajar adalah faktor yang mempengaruhi kualitas output mahasiswa (Cahyani et al., 2020). Hasil penelitian Sur et al (2020) menunjukan bahwa proses belajar yang dilakukan secara daring berpengaruh kepada motivasi mahasiswa dalam belajar hal ini ditunjukan dengan hasil $t$ hitung yang lebih besar dari ada t table $(4,419>2,010)$ yang dianalisis dengan regresi linear sederhana.. Dengan dasar ini, maka tujuan penelitian ini adalah untuk mengetahui dan menjelaskan pengaruh persepsi mahasiswa sistem informasi UKSW Salatiga tentang metode pembelajaran daring terhadap motivasi belajar di masa pandemi Covid-19.

\section{METODE PENELITIAN}

Jenis penelitian ini merupakan penelitian kuantitatif deskriptif yang semua informasi atau data penelitian diwujudkan dalam bentuk angka yang dianalisis dengan statistik dan dideskripsikan dalam bentuk narasi (Arikunto, 2013). Pada penelitian ini subjek yang disasar mahasiswa aktif angkatan 2019/2020 Program Studi Sistem Informasi UKSW. Dalam penelitian ini peneliti menggunakan instrumen kuisioner untuk mengumpulkan data yang disajikan dalam bentuk media google-form dan disebar secara online. Kuisioner dimuat dalam pernyataan yang akan dijawab oleh responden dengan memilih pilihan jawaban berdasarkan penggunaan skala likert dengan 5 alternatif jenis respon yaitu "sangat setuju", "setuju", "ragu-ragu", "tidak setuju", dan "sangat tidak setuju" (Sugiyono, 2007).

Analisis data menggunakan program software SPPS Versi 20.0. dengan analisis univariat dan bivariat pada indikator yang ditanyakan. Analisis univariat dilakukan terhadap masing-masing variabel independent (Persepsi mahasiswa tentang metode pembelajaran daring) dan dependen (Motivasi belajar mahasiswa angkatan 2019/2020 Program Studi Sistem Informasi UKSW). Analisi bivariat dilakukan untuk menganalisis hubungan antar variabel dengan menggunakan uji Spearman berdasarkan tingkat kemaknaan $\alpha=0,005$. Bila nilai $p<0,05$ maka ada pengaruh antara 2 variabel tersebut.

\section{HASIL DAN PEMBAHASAN}

\section{Analisis Univariat Data tentang Persepsi Mahasiswa}

Dalam penelitian ini data persepsi dan motivasi belajar mahasiswa program studi SI UKSW diperoleh melalui kuesioner dengan jumlah 35 Butir pertanyaan dengan 
Prisilia Tehupuring , Adriyanto J. Gundo

Hubungan Persepsi terhadap Metode Pembelajaran Daring dengan Motivasi Belajar Mahasiswa Program Studi Sistem Informasi-UKSW

Prima Magistra: Jurnal Ilmiah Kependidikan Volume 3, Nomor 1, Januari 2022, hal 71-84

didasarkan pada 2 variabel. Berikut ini hasil

Analisa deskriptif pada masing-masing

variabel.

Tabel 1 Nilai-Nilai Statistik Skor Persepsi Mahasiswa SI

\begin{tabular}{ccccccc}
\hline Mean & Median & Modus & Min & Makx & SD & P-value \\
36.34 & 37.00 & 34 & 26 & 67 & 7.433 & 0.003
\end{tabular}

Tabel 1 di atas menunjukan bahwa rata- standar deviasi adalah 77,433. rata skor persepsi responden adalah 36,34 Berdasarkan hasil Kolmogorov Smirnov, median skor persepsi adalah 37,00, skor persepsi diketahui terdistribusi tidak modus skor persepsi adalah 34, skor normal dengan nilai $P$-value yaitu $>0,05$ persepsi terendah adalah 26, skor yaitu 0,003, sehingga dasar yang dipakai persepsi tertinggi adalah 67 dengan adalah nilai median.

Tabel 2 Distribusi Frekuensi Persepsi Mahasiswa Berdasarkan Jenis Kelamin

\begin{tabular}{|c|c|c|c|c|}
\hline & & \multicolumn{2}{|c|}{ Persepsi n (\%) } & \multirow[t]{2}{*}{ Total } \\
\hline & & Positif & Negatif & \\
\hline \multirow[t]{2}{*}{ Jenis Kelamin } & Laki-Laki & $12(34.3 \%)$ & $23(65.7 \%)$ & $35(100 \%)$ \\
\hline & Perempuan & $5(17.2 \%)$ & $24(82.8 \%)$ & $29(100 \%)$ \\
\hline Total & & $17(26.6 \%)$ & $47(73.4 \%)$ & $64(100 \%)$ \\
\hline
\end{tabular}

Tabel 2 menunjukkan bahwa responden laki- pembelajaran daring dimana pada laki-laki laki dan perempuan mayoritas memiliki sebanyak 23 orang (65.7\%) dan pada persepsi negatif terhadap metode perempuan sebanyak 24 orang (82.8\%).

Tabel 3 Distribusi Frekuensi Persepsi Mahasiswa Berdasarkan Domisili

\begin{tabular}{rlccc}
\hline & & \multicolumn{2}{c}{ Persepsi n (\%) } & Total \\
\cline { 3 - 5 } Domisili & Positif & Negatif & \\
& Kawasan Barat Indonesia & $10(21.7 \%)$ & $36(78.3 \% \%)$ & $46(100 \%)$ \\
& Kawasan Timur Indonesia & $7(38.9 \%)$ & $11(61.1 \%)$ & $18(100 \%)$ \\
\hline Total & & $\mathbf{1 7}(\mathbf{2 6 . 6 \%})$ & $\mathbf{4 7}(\mathbf{7 3 . 4 \%})$ & $\mathbf{6 4}(\mathbf{1 0 0 \%})$ \\
\hline
\end{tabular}

Tabel 3 menunjukkan bahwa responden laki-laki sebanyak 23 orang $(65,7 \%)$ dan laki-laki dan perempuan mayoritas pada perempuan sebanyak 24 orang memiliki persepsi negatif terhadap (82,8\%). metode pembelajaran daring dimana pada

Tabel 4 Distribusi Frekuensi Motivasi Belajar Berdasarkan Jenis Kelamin

\begin{tabular}{|c|c|c|c|c|}
\hline & & Motivas & $\begin{array}{l}\text { i Belajar n } \\
\%)\end{array}$ & Total \\
\hline & & Tinggi & Rendah & \\
\hline \multirow{2}{*}{$\begin{array}{l}\text { Jenis } \\
\text { Kelamin }\end{array}$} & Laki-Laki & $23(65.7 \%)$ & $12(34.3 \%)$ & $35(100 \%)$ \\
\hline & Perempuan & $15(51.7 \%)$ & $14(48.3 \%)$ & $29(100 \%)$ \\
\hline Total & & $37(57.8 \%$ & $27(42.2 \%)$ & $64(100 \%)$ \\
\hline
\end{tabular}

Tabel 4 dapat diketahui bahwa responden pada penelitian ini sebagian besar memiliki motivasi belajar yang tinggi terkait metode pembelajaran daring di masa pandemi COVID-19, dan di dominasi oleh responden angkatan 2020 yaitu sebesar 22 orang $(64,7 \%)$. Sedangkan angkatan 2019, memiliki motivasi belajar yang rendah dan motivasi belajar yang tinggi dengan presentase yang sama yakni masingmasing 15 responden $(50,0 \%)$.

\section{Analisis Bivariat}

Hubungan persepsi terhadap metode pembelajaran daring dengan motivasi belajar mahasiswa Program Studi SI, UKSW selama pandemi Covid-19 dianalisis dengan menggunakan uji Spearman. Hasil analisis bivariat dapat dilihat pada tabel 5 . 
Prisilia Tehupuring , Adriyanto J. Gundo

Hubungan Persepsi terhadap Metode Pembelajaran Daring dengan Motivasi Belajar Mahasiswa Program Studi Sistem Informasi-UKSW

Prima Magistra: Jurnal Ilmiah Kependidikan Volume 3, Nomor 1, Januari 2022, hal 71-84

Tabel 5 Hasil Analis Bivariat Persepsi Metode Pembelajaran Daring Dengan Motivasi Belajar

\begin{tabular}{|c|c|c|c|c|c|c|c|}
\hline \multirow[b]{2}{*}{ PERSEPSI } & \multicolumn{2}{|c|}{ MOTIVASI } & \multirow{2}{*}{ Total } & \multirow{2}{*}{$P$} & \multirow[b]{2}{*}{$\mathbf{r}$} & \multirow{2}{*}{$\mathbf{P R}$} & \multirow{2}{*}{$95 \%$ CI } \\
\hline & Tinggi & Rendah & & & & & \\
\hline Positif & $14(82.4 \%)$ & $3(17.6 \%)$ & $17(100 \%)$ & \multirow{3}{*}{0.016} & \multirow{3}{*}{0.299} & \multirow{3}{*}{4.870} & \multirow{3}{*}{$\begin{array}{c}1.235- \\
19.199\end{array}$} \\
\hline Negatif & $23(48.9 \%)$ & $24(51.1 \%)$ & $47(100 \%)$ & & & & \\
\hline Total & $37(57.8 \%)$ & $27(42.2 \%)$ & $64(100 \%)$ & & & & \\
\hline
\end{tabular}

Dari hasil uji analisis bivariat diperoleh nilai $p=0,016$ dimana nilai $p<$ 0,05 . Hal ini bermakna bahwa terdapat hubungan antara persepsi terhadap metode pembelajaran daring dengan motivasi belajar mahasiswa Program Studi SI, angkatan 2019 dan 2020 UKSW selama pandemi COVID-19, dengan kekuatan korelasi lemah, yaitu 0,299 . Nilai koefisien korelasi yang positif menunjukkan hubungan yang searah. Hasil analisis kedua variabel ini menunjukkan nilai rasio prevalens sebesar 4,870 dengan rentang nilai 95\% CI adalah 1,235-19,199.

\section{Persepsi Mahasiswa Program Studi Sistem Informasi, UKSW Terkait Metode Pembelajaran Daring}

Persepsi mahasiswa terhadap proses pembelajaran daring selama masa pandemi ini belum dapat diketahui secara valid dalam hal kesiapan mahasiswa maupun kendala yang didapatkan selama pelaksanaan proses pembelajaran daring hal ini diakibatkan karena kondisi pandemi yang datang secara tiba-tiba dan juga pemberlakuan pembelajaran yang awalnya ditiadakan menjadi pembelajaran daring. Dari perubahan sistem pembelajaran ini tentu saja berdampak terhadap kondisi Pendidikan (Simatupang et al., 2020) sehingga untuk tetap menjaga keaktifan dan peran mahasiswa dalam menggunakan media dan teknologi sebagai kebijkan dalam menjalankan pembelajaran daring sangatlah dipengaruhi ileh persepsi (Wibowo, 2016). Persepsi negative dimunculkan ketika pengetahuan akan tahu tidaknya, kenal tidanya bahkan respon individu yang ttidak dapat menerima objek yang dipersepsikan.

\section{Persepsi Mahasiswa Berdasarkan Jenis Kelamin}

Berdasarkan hasil penelitian diatas menunjukan bahwa mayoritas responden memiliki persepsi negatif terkait pelaksanaan metode pembelajaran daring. Berdasarkan jenis kelamin, mahasiswa perempuan memiliki persepsi negatif yang lebih dari laki-laki. Sejalan dengan penelitian Rahmaniati \& Bulkani (2020) bahwa perbedaan fokus antara seorang dengan lainnnya sebagi bentuk dari pengaruh faktor internal menyebabkan adanya perbedaan persepsi sehingga laki-laki cenderung mempunyai perkembangan emosi yang baik dari perempuan. Pada laki-laki kematangan emosi ini memberikan arti laki-laki lebih mampu bersikap bijaksana dalam hal ini lebih objektif, mampu dengan mudah menyesuaikan diri, menangani masalah tanpa memihak, tidak bergantung pada orang lain, bersimpati, dan menyukai tantangan. Hasil studi Kusuma et al. (2021) menegaskan bahwa perbedaan antara laki-laki dan perempuan ini dapat didasarakan pada perbedaan biologis sehingga masing-masing dapat mengembangkan persepsi yang berbeda. Dilanjutkan oleh Setyawan (2016) bahwa laki-laki dan perempuan memiliki pengaruh secara gender dalam melakukan peranan memoderasi pengaruh faktor internal maupun eksternal terhadap persepsi mahasiswa.

Jika dihubungkan dengan pengisian kuisioner penelitian tentang persepsi mahasiswa, diketahui bahwa mayoritas mahasiswa laki laki adalah yang paling banyak mendukung pelaksanaan metode pembelajaran daring di UKSW, namun juga merupakan mayoritas yang ragu-ragu dalam kesediaannya melaksanakan pembelajaran daring. Kecenderungan mahasiswa laki-laki dan juga perempuan pada Program Studi SI, UKSW merasa bahwa metode daring tidak efektif dalam proses belajar mengajar. Tidak ada masalah terkait kemampuan dosen maupun waktu masuk dosen atau tim pengajar karena mayoritas berpersepsi bahwa dosen mampu memberikan layanan ajar yang baik melalui metode daring. Efek yang lebih 
dirasakan hanyalah pada output dari mahasiswa laki-laki maupun perempuan yang mayoritas menyatakan persepsi negatifnya melalui jawasan tidak setuju pada unsur item terkait keaktifan mahasiswa pada dalam proses metode pembelajaran daring. Interaksi antar mahasiswa dan dosen serta pelaksanaan simulasi atau latihan tertentu pun dirasakan tidak optimal. Selain itu, walaupun mahasiswa laki-laki memiliki persepsi yang lebih positif, namun mereka mengakui bahwa mayoritas dari mereka merasa termasuk mahasiswa perempuan merasa bosan dengan metode daring yang menurut persepsi mereka metode daring terlalu monoton, sehingga hal ini menimbulkan mayoritas mahasiswa baik laki-laki maupun perempuan pada angkatan 2019 dan 2020 kurang merasa memiliki peluang untuk belajar. Penelitian internasional yang dilakukan di AS memberikan hasil teliti bahwa laki-laki memiliki banyak persepsi yang positif terkait pembelajaran daring dari wanita. Penelitian internasional mendukung temuan sebelumnya di AS yang membuktikan gagasan bahwa laki-laki memiliki lebih banyak persepsi positif tentang pembelajaran online daripada wanita. Song et al (2004) perbedaan gender, persepsi adalah faktorfaktor yang mempengaruhi porses penerimaan akan pembelajaran daring (online)

\section{Persepsi Mahasiswa Berdasarkan Angkatan (Tahun Masuk)}

Berdasarkan hasil penelitian ini, diketahui bahwa angakatan 2020 memiliki persepsi negatif lebih banyak dibandingkan dengan angkatan 2019. Rata-rata institusi Pendidikan telah menggunakan pembelajaran daring sebagai satu-satunya cara paling solutif untuk tetap mengaktifkan proses belajar mengajar sekaligus sebagai upaya memutus rantai penyebaran virus sehingga dapat menjaga keamanan, keselamatan peserta didik dan tenaga pendidik (Zhafira et al., 2020). Angkatan 2020 merupakan angkatan istimewa yang dijuluki sebagai "angkatan corona", yang secara langsung harus menyesuaikan diri dengan sistem pendidikan darurat pandemi (COVID-19) yaitu metode daring. Keadaan transmisi menuju ke bidang ilmu yang lebih spesifik akan terasa lebih sulit karena penyesuaian awal yang kurang memadai, menuntut mahasiswa untuk dapat memaksakan diri dalam belajar mandiri. Hal ini pun dikarenakan oleh waktu dan proses interaksi yang kurang memberikan ruang gerak sehingga membatasi ranah mahasiswa dalam memahami maupun mengelaborasikan pemahamannya terkait bidang ilmu yang dipelajari. Turut disampaikan dalam penelitian Megawanti, dkk bahwa Pembelajaran daring yang telah dilakukan pada masa pandemi (Tahun Akademik 2019/2020) program studi bidang teknologi berjalan dengan baik namum tidak dapat dipungkiri juga bahwa ada mahasiswa yang lebih menyukai pembejaraan sebelum pandemic (offline). Adanya mahasiswa yang lebih menyukai pembelajaran sebelum pandemic ini sejalan juga dengan penelitian bahwa selama pembelajaran daring ini membuat interaksi antara mehasiswa dan dosen menjadi terbatas dan penyampaian materi juga kurang maksimal (Megawanti et al., 2020). Hasil penelitian Marthika (2020) juga menyatakan bahwa dari 30 mahasiswa baru anngkatan 2020 yang dianalisis, 48,3\% yang menyatakan keraguan dalam memiliki antusiasme mengikuti kuliah online; 34,5\% mahasiswa menyatakan setuju untuk pelaksanaan kuliah offline; dan 41,4\% mahasiswa mengakui pembelajaran konvensional (offline) lebih efektif dibandingkan pembelajaran online. Owusu, dkk dalam hasil penelitiannya pun menyimpulkan bahwa pembelajaran daring berdampak negatif karena Platform $e$ learning yang digunakan menjadi tantangan bagi mayoritas begitupun dengan keterbatasan akses internet (Ansah, 2020). Akibatnya sebagian besar mahasiswa memiliki persepsi yang negative akan pembelajaran daring apabila diperpanjang karena akan berdampak kepada kurang maksimalmya penyampaian materi juga pemahaman dan kejenuhan yang bisa dialami oleh mahasiswa. Hal ini menimbulkan pertanyaan apakah dengan menggunakan teknologi ini mampu untuk menggantikan peranan pendidik atau sebaliknya tidak dapat tergantikan oleh teknologi. Jika dihubungkan dengan kuisioner penelitian terkait persepsi 
mahasiswa terhadap metode pembelajaran daring, diketahui bahwa mayoritas angkatan 2020 setuju dengan pelaksanaan metode ini, namun mayoritas dari mereka pun mengaku tidak sanggup dan tidak siap untuk pelaksanaan metode pembelajaran daring. Efektifitas yang dinilai oleh angkatan 2020 mayoritas memberikan respon tidak setuju dengan pernyataan ketidaksetujuan mahasiswa angkatan 2020 karena pemahaman materi yang kurang maksimal. Begitupun dengan interaksi dan keaktifan mahasiswa angkatan 2020 yang tidak maksimal di kelas online serta merasa bahwa metode pembelajaran daring memberikan efek bosan dan tidak fokus selama proses metode pembelajaran daring.

\section{Persepsi Mahasiswa Berdasarkan Wilayah Domisili}

Berdasarkan penelitian ini pun ditemukan hasil bahwa mayoritas mahasiswa yang berdomisili di kawasan Barat Indonesia memiliki persepsi negatif lebih banyak dibandingkan dengan yang berdomisili di kawasan Timur Indonesia. Secara garis besar ini mampu mematahkan asumsi terkait permasalahan di wilayah Timur Indonesia yang selalu identik dengan wilayah serba memiliki kekurangan dan keterbelakangan. Selain dilihat berdasarkan jumlah responden secara substantif terdapat selisih sebanyak $9,8 \%$ perbedaan persepsi mahasiswa berdasarkan kawasan Barat dan Timur Indonesia, sedangkan secara spesifik persepsi negatif antara dua wilayah domisili tersebut terdapat selisih perbedaan persepsi sebesar 17,2\% yang didominasi oleh kawasan Barat Indonesia. Persepsi negatif yang muncul ini berhubungan dengan hambatan pelaksanaan metode pembelajaran daring yaitu terkait permasalahan jaringan internet. Hal ini tertera dalam hasil penelitian Yaumi (2018) menyebutkan dalam keterbatasan akses internet, perangkat keras dan lunak (hardware dan software) menjadi kendala yang besar dalam memaksimalkan sumber sumber belajara onlines. Hambatan yang dimaksud adalah singnal yang lemah sehingga menimbulkan ketidak stabilan jaringan online (Iskandar et al., 2020). Hal ini didukung juga oleh hasil survei Ditjen Dikti Kemendikbud tentang "Evaluasi
Persepsi Pembelajaran Jarak Jauh" yang mana didapati $90 \%$ mahasiswa memilih untuk pelaksanaan kuliah konvensional dibandingkan daring karena mahasiswa tidak siap dan juga kendala lain saat pembelajaran daring kendala jaringan dan hasil penelitian Andriani \& Wahyuni (2021) dimana 54\% mahasiswa menyatakan bahwa kendala terbesar dalam pelaksanaan metode daring. Berdasarkan wilayah domisili, tinggi di kawasan Barat Indonesia tidak serta-merta menjamin bahwa tidak terdapat masalah terkait jaringan internet. Ternyata masalah yang sama dirasakan oleh semua mahasiswa baik di kawasan Timur maupun Barat Indonesia. KEMKOMINFO melaporkan dari keseluruhan daerah Indonesia terdapat beberapa daerah yang tidak tersedia jaringan LTE yaitu sebanyak kurang lebih 9.113 dan yang tidak tersedia jaringan LTE sebanyak 3.435 , sehingga dari keseluruhan daerah ini terdapat 12.548 daerah yang tidak terdapat jaringan nirkabel ini dan merupakan daerah blank spot (tidak adanya jaringan fiber optic sebagai penghubung dari base transceiver station (BTS). Hal ini berarti daerah-daerah di Indonesia belum memiliki kesetaraan akses internet. Perusahan Ookla melakukan analisis terhadap kecepatan download dan upload juga tersedianya jaringan LTE berdasarkan 5 operator seluler yang tersedia dan didapatkan hasil bahwa ada 4 Provinsi memiliki kecepatan jaringan Papua Barat, Bali, Maluku dan Gorontalo berturut-turut 20,14 Mbps, 19,68 Mbps, 19,43 Mbps 19,32 Mbps. Hal ini sebenarnya dikarenakan dinamika persaingan dan permintaan. Hal ini dikarenakan banyaknya pengguna yang terhubung akan menurunkan kecepatan ratarata meskipun operator sudah melakukan peningkatan terhadap jaringan dan kapasitas pada kota besar namun tetap masih belum cukup untuk mengimbangi permintaan data seluler, Sehingga, persepsi negatif tersebut hanya dikarenakan faktor ketidaktahuan mahasiswa bahwa pengendalian server jaringan menjadi terganggu karena pemakaian dan permintaan yang memingkat khususnya di masa pandemi Covid-19. Jika dihubungkan dengan kuisioner penelitian pun, didapati bahwa mayoritas dari mahasiswa yang berdomisili di kawasan Barat dan Timur Indonesia sama-sama 
memiliki persepsi positif terkait pelaksanaan metode daring di Progdi SI UKSW, namun mereka memiliki persepsi negatif terkait kesanggupan mereka untuk melaksanakan metode tersebut dan lebih sering tidak fokus selama pembelajaran daring. Hampir seluruh item pernyataan memiliki kuantitas yang tidak jauh berbeda terkait persepsi mahasiswa tentang keefektifan metode pembelajaran daring bagi mahasiswa yang berdomisili di kawasan Barat maupun Timur Indonesia. Dengan adanya perbedaan lokasi yang ada, dosen tidak dapat melakukan pengamatan secara langsung apakah mahasiswa masih terhubung dengan proses perkuliahan yang berlangsung sehingga dosen juga mengalami kendala untuk memastikan apakah mahasiswa dapat mendengkarkan dan mengikuti perkuliahan dengan baik (Sriharan, 2020).

Motivasi Mahasiswa Belajar Angkatan 2019 dan 2020, Fakultas Teknologi Informasi, UKSW di Masa Pandemi Covid-19

Kondisi pandemi memberikan ruang pada perkembangan proses perkuliahan daring sehingga proses ini dipastikan akan berbeda dengan proses perkuliahan sebelum pandemi dan dibutuhkan ketrampilann dalam penggunaan media teknologi oleh pendidik (de Jong, 2020), dibalik proses pembelajaran yang berbeda antara sebelum dan sesudah pandemi ini menuntut mahasiswa untuk tetap manjaga motivasi dan terus meningkatkannya agar selama proses ini tetap dapat berjalan dengan baik. Motivasi adalah sebuah dorongan psikis individu yang ada untuk menggerakan individu untuk melakukan sesuatu . Berdasarkan penelitian yang telah dilakukan ini menunjukan bahwa sebagain besar mahasiswa Program Studi SI UKSW memiliki motivasi tinggi selama menjalani metode pembelajaran daring yaitu sebanyak 37 orang dari 64 responden $(57,8 \%)$. Berdasarkan uji pengaruh dari penelitian Desriva et al (2020) menunjukan hasil korelasi yang signifikan dengan nilai $\mathrm{p}=0,000$ berdasarkan Pired sample T-test sehingga dari uji ini didapatkan bahwa adanya pengaruh yang signifikan antara metode yang digunakan dalam pembelajaran dengan motivasi belajar mahasiswa, hasil ini didukung dengan penelitian lain yang menyatakan bahwa mayoritas mahasiswa memiliki motivasi yang tinggi dalam mengikuti proses perkuliahan daring (Suryana et al., 2020).

\section{Motivasi Belajar Mahasiswa Berdasarkan Jenis Kelamin}

Berdasarkan hasil responden mununjukan bahwa mahasiswa laki-laki memiliki motivasi yang tinggi dalam melaksanakan proses pembelajaran daring sebanyak $65,7 \%$. Studi meta menyimpulkan laki-laki mempunyai kemampuan dalam mengoperasikan komputer lebih baik dari perempuan (Meece et al., 2006). Jika dilihat dari hasil kuisioner yang didapat menunjukan selama masa pandemi ini proses penyampaian materi perkuliahan tidak semuanya dinikmati oleh mahasiswa. Walaupun terdapat beberapa mahasiswa lakilaki yang menyatakan ragu terhadap ketertarikan materi belajar melalui media daring, namun mahasiswa perempuan memiliki presentase yang lebih dominan dalam keraguannya menyukai materi pembelajaran yang ditampilkan melalui media daring yaitu sebanyak $60,7 \%$. Bussey \& Bandura (1999) menyatakan laki-laki lebih memiliki sikap positif dalam akitivitas menggunakan komputer dan menunjukan ketertarikan yang lebih juga karena intensitas laki-laki menggunakan komputer lebih sering dari wanita.

Meskipun begitu, bukan berarti bahwa mahasiswa perempuan tidak menaruh rasa ingin tahu terhadap bidang ilmunya. Hal ini terlihat pada item pernyataan terkait jadwal belajar mandiri sebanyak yang ditemukan pada mahasiswa laki-laki dan perempuan yaitu sebanyak 50\%. Begitupun juga pada item pernyataan terkait inisiatif bertanya saat di kelas ketika mahasiswa tidak memahami materi yang disampaikan, mahasiswa menunjukan sikap yang lebih aktif saat bertanya yaitu dengan presentase $55,2 \%$, namun perempuan juga memiliki motivasi yang tidak kalah jauhnya yaitu sebanyak $44,8 \%$. Selama proses pembelajaran daring mahasiswa dapar menjawab pertanyaan dengan baik dengan presentase laki-laki $55 \%$ dan perempuan $45,1 \%$. Hasil ini sejalan dengan dukungan 
penelitian dari Firman \& Rahman (2020) yaitu pada masa pendemi pembelajaran lebih fleksibel sehingga mendorong kemandirian mahasiswa untuk belajar dan memotivasi untuk lebih aktif. Penelitian Hasanah et al (2020) menyatakan bahwa aktivitas mahasiswa berada pada katagori cukup baik.

\section{Motivasi Belajar Mahasiswa Berdasarkan Angkatan (Tahun Masuk)}

Berdasarkan hasil penelitian ini didapati bahwa angkatan 2020 memiliki motivasi yang lebih tinggi daripada angkatan 2019 yaitu sebanyak 15 orang $(64,7 \%)$ dari 30 responden sedangkan angkatan 2019 sebanyak 22 orang (50\%) dari 34 responden. Mahasiswa angkatan 2020 merupakan mahasiswa baru yang dalam prosesnya masih memerlukan adaptasi yang lebih sehingga tidak dapat dipungkiri bahwa angkatan 2020 memberikan fokus yang lebih meskipun metode pembelajaran yang diberlakukan adalah metode daring. Jika dihubungkan dengan item kuisioner penelitian terkait motivasi belajar diketahui bahwa mahasiswa angkatan 2020 lebih aktif dalam memberikan pertanyaan kepada dosen saat tidak memahami pelajaran yaitu sebanyak 59\% dari 22 orang yang memiliki motivasi tinggi.

Ada 2 hal yang dapat mempengaruhi tingginya suatu motivasi yaitu secara intrinsik dan ekstrinsik. Jika dilihat secara intrinsik motivasi terbentuk ketika rasa ingin tahu dalam diri tinggi, adanya kemampuan untuk mencapai suatu tujuan dan kemampuan intelektual yang sudah ada sebelumnya dalam diri mahasiswa, sedangkan secara ekstrinsik motivasi terbentuk ketika mendapat nilai yang tinggi sehingga mendorong untuk terus mendapat nilai yang tinggi (Rücker, 2012). Hal tersebut terlihat pada mahasiswa angkatan 2020 yang menunjukan segi kompetitif melalui item pernyataan terkait "Jika nilai hasil ujian saya tinggi, saya berusaha mempertahankan dengan belajar lebih keras lagi", dengan memberikan respon sangat setuju sebanyak $54,2 \%$. Selain itu, mahasiswa angkatan 2019 dan angkatan 2020 pun mampu meluangkan waktu dengan baik untuk belajar mandiri. Ada juga hasil penelitian yang menunjukan terdapat sebanyak 80\% angkatan 2019 dan angkatan 2020 sebanyak 63,6\% mahasiswa dari total keseluruhan yaitu 15 responden (angkatan 2019) dan 22 responden (angkatan 2020) yang memiliki motivasi tinggi untuk membuat jadwal belajar mandiri. Begitu juga dengan kebiasaan menumpuk tugas, tidak dipungkiri bahwa keluhan terkait tugas yang begitu banyak dimasa pandemi memberikan rasa semangat yang kurang. Namun, ternyata hasil penelitian ini menunjukan hasil yang sebaliknya, dimana angkatan 2020 sebagai angkatan baru mampu menunjukan konsistensinya dalam memanajemen diri sehingga menghindari penumpukan tugas. Terlihat dari presentase pada item pernyataan terkait motivasi (No.13) yaitu "Saya berusaha untuk tidak menumpuk tugas kuliah" dilakukan oleh mahasiswa angkatan 2019 (67\%) dan angkatan 2020 (59\%). Menurut penelitian Muhammad (2020) menyimpulkan dalam pembelajaran daring selama masa pandemi berpengaruh kepada peningkatan kemadirian mahasiswa dalam belajar.

\section{Motivasi Belajar Mahasiswa Berdasarkan Wilayah Domisili}

Lingkungan belajar menjadi sangat berpengaruh untuk motivasi belajar mahasiswa Juliawan (2020) dan memiliki peranan yang penting untuk menciptakan suasana belajar yang nyaman, tenang dan memotivasi mahasiswa untuk melakukan pembelajaran (Radovan \& Makovec, 2015). Dengan adanya motivasi yang tinggi tentunya sangat diperlukan untuk tetap menjaga agar tidak mengalami kertertinggalan dalam pembelajaran sehingga dapat tercapainya tujuan dan cita-cita. (Suharto, 2009). Belum banyak penelitian yang menganalisis terkait permasalahan di Indonesia bahwa apakah adanya perbedaan yang cukup singkifikan terhadap penggunaan metode daring dalam pembelajran kawasan bagian Barat Indonesia maupun kawasan Timur Indonesia serta apakah terdapat pengaruh atau hubungan dengan motivasi belajar mahasiswa ataukah tidak. Bila berbicara tekait wilayah domisili dan hubungannya dengan metode belajar daring secara umum, sama halnya dengan masalah yang susah tidak lazim yaitu terkait jaringan. 
Namun apakah hal tersebut memberikan dampak tersendiri bagi motivasi mahasiswa?

Berdasarkan Kemendikbud (2020) di Indonesia ada $31,8 \%$ daerah yang belum memeiliki ketersedaian jaringa internet dan $7.1 \%$ belum adanya listrik yang masuk sehingga jika dalam proses pembelajarn daring yang dilakukan memberikan nilai yang berbeda pada setiap instansi Pendidikan dikarenakan kebijakan yang dibuat pemerintah ini menimbulkan persoalan lagi kepada wilyah bagian barat dan timur dalam segi aksesbilitas terhdap jaringan dan teknologi begitu juga dengan penyediaan akan arus listrik. Dari perbedaan ini menumbuhkan bias yang cukup besar antar daerah terkoneksi internet dan daerah yang tidak terjangkau akses internet dan teraliri listrik. Berdasarkan penelitian yang telah dilakukan pada wilayah timur khususnya di Nusa Tenggara Timut (NTT) sekitar bulan maret instansi Pendidikan telah melakukan upya untuk mengganti kegiatan Pendidikan tatap muka menjadi pembelajaran virtual. Meskipun adanya kendala yang dialami pada proses pelaksanaan pembelajaran virtual ini seperti contohnya kesulitan untuk mmemperhatikan penyampaian materi melalui sistem daring namum kebijakan penggunaan pembelajaran daring inti menjadi cara yang dirasa lebih baik untuk tetap menjaga keberlangsungan aktivitas pendidikan selama masa pandemi covid-19 (Arkiang, 2021). Dalam penelitian ini pun, ditemukan bahwa secara kuantitas presentase mahasiswa yang memiliki motivasi tinggi dan berdomisili di kawasan Barat Indonesia lebih banyak yaitu $65,2 \%$ dari total 30 mahasiswa dibandingkan dengan mahasiswa yang berdomisili di kawasan Timur Indonesia yang memiliki motivasi lebih rendah yaitu 42,2\% dari total 7 mahasiswa.

Penelitian-penelitian terdahulu yang terkait dengan masalah ini pun lebih banyak pada ranah sekolah dan belum banyak yang mengulas terkait permasalah yang dialami oleh mahasiswa. Namun penelitian ini memberikan kesimpulan melalui item pernyataan tentang "Saya terkadang mulai malas bila terjadi masalah jaringan atau koneksi internet saat proses belajar mengajar" dimana total kategori respon setuju dan sangat setuju dari mahasiswa yang memiliki motivasi tinggi dan yang berdomisili di kawasan Barat Indonesia memiliki presentase $80 \%$, sedangkan mahasiswa yang memiliki motivasi tinggi di kawasan Timur Indonesia memiliki presentase $85,7 \%$ dari 7 mahasiswa dan yang memiliki motivasi rendah berjumlah $81,8 \%$ dari 11 mahasiswa yang berdomisili di kawasan Timur Indonesia. Hal ini membuktikan bahwa meskipun kuantitas mahasiswa yang memiliki motivasi rendah dan tinggi di kawasan Timur Indonesia memiliki perbedaan yang begitu besar, namun masih terdapat mahasiswa yang tetap tidak memilih untuk patah semangat dan tetap berusahan beradaptasi dengan situasi pandemi. Hal ini patut menjadi masukan dan perhatian khusus untuk manajemen pendidikan darurat nantinnya. Sama halnya dengan masalah tersebut, Nurcita \& Susantiningsih (2020) menyatakan dalam penelitiannya bahwa kendala pembelajaran daring ini dapat disebabkan oleh ketersediaan infrasturktur komunikasi sehingga berpengaruh juga akan ketersediaan jaringan internet pada pulau jawa dan luar jawa dan mengakibatkan lemahnya pembelajaran daring ini,

\section{Hubungan Persepsi Terhadap Metode Pembelajaran Daring Dengan Motivasi Belajar Mahasiswa Program Studi SI UKSW di Masa Pandemi Covid-19}

Hasil peneiltian yang didapat dengan uji spearman memperoleh nilai p 0.016 ini memberikan arti bahwa adanya hubungan antara persepsi mahasiswa terhadap metode pembelajaran daring yang digunakan dengan motivasi belajar mahasiswa program studi sistem informasi UKSW selama pandemi covid 19. Hal ini juga didukung oleh penelitian yang relevan yaitu Dewi (2021) dengan sasaran penelitian mahasiswa kedokteran Universitas Sumatera Utara dengan menggunakan uji Spearman dan didapatkan nilai $\mathrm{p}$ sebesar 0,001 sehingga dapat disimpulkan juga persepsi yang dimiliki oleh seseorang merupakan bentuk dari penilaian diri akan suatu objek yang dilihat atau diamati. Kepuasan mahasiswa dalam mengikuti pembelajaran dalam suatu institusi merupakan salah satu aspek yang 
Prisilia Tehupuring , Adriyanto J. Gundo

Hubungan Persepsi terhadap Metode Pembelajaran Daring dengan Motivasi Belajar Mahasiswa Program Studi Sistem Informasi-UKSW

Prima Magistra: Jurnal Ilmiah Kependidikan Volume 3, Nomor 1, Januari 2022, hal 71-84

penting dan Lembaga Pendidikan Tinggi (Sur et al., 2020). Menurut penelitian motivasi intrinstik yang dimiliki oleh mahasiswa selama proses pembelajaran daring lebih tinggi dari pada proses pembelajaran secara tatap muka (Rovai et al., 2007). Motivasi sebagai salah satu faktor yang penting dan dibutuhkan guna mendukung keberhasilan pembelajaran termasuk kepada pembelajaran masa pandemi (Harandi, 2015). Dengan penelitian yang telah dilakukan ini menunjukan bahwa adanya hubungan persepsi mahasiswa akan penggunaan metode pembelajaran dengan motivasi belajar didukung juga dengan sampel yang mamadai. Namum selama penyebaran kuisioner penelitian secara online dengan google form dalam waktu yang singkat peneliti tidak dapat memastikan variabel lain yang berpengaruh dalam pengisian angket.

\section{SIMPULAN DAN SARAN}

Berdasarkan hasil penelitian dan pembahasan maka dapat disimpulkan bahwa terdapat hubungan antar persepsi dan motivasi belajar mahasiswa terhadap metode pembelajaran daring. Selain itu, penelitian ini juga memberikan saran bagi peneliti selanjutnya agar dapat meneliti lebih dalam mengenai variabel-variabel yang dapat mempengaruhi motivasi belajar.

\section{DAFTAR PUSTAKA}

Andriani, R., \& Wahyuni, S. (2021). Identifikasi Persepsi Mahasiswa dan Hambatan dalam Perkuliahan Daring Menggunakan Technology Acceptance Model (TAM). Jurnal Ilmiah Profesi Pendidikan, 6(3), 397-404. http://www.jipp.unram.ac.id/index.php/ jipp/article/view/230

Andriani, R., \& Rasto, R. (2019). Motivasi belajar sebagai determinan hasil belajar siswa. Jurnal Pendidikan Manajemen Perkantoran (JPManper), 4(1), 80-86. https://doi.org/10.17509/jpm.v4i1.1495 8

Ansah, S. O. (2020). S.W.O.T Analysis Of ELearning Platform, Sakai: Users' Perspective. University of NebraskaLincoln. https://digitalcommons.unl.edu/libphilp $\mathrm{rac} / 3601$

Arikunto, S. (2013). Prosedur Penelitian: Suatu Pendekatan Praktik. In Jakarta: Rineka Cipta. Google Scholar

Arkiang, F. (2021). Analisis pembelajaran daring selama pandemi COVID-19 di daerah 3T (Nusa Tenggara Timur). Jurnal Pendidikan, 12(1), 5764.

https://jp.ejournal.unri.ac.id/index.php/J P/article/view/7917

Bussey, K., \& Bandura, A. (1999). Social Cognitive Theory of Gender Development and Differentiation. Psychological Review, 106(4), 676713. https://doi.org/10.1037/0033295X.106.4.676

Cahyani, A., Listiana, I. D., \& Larasati, S. P. D. (2020). Motivasi Belajar Siswa SMA pada Pembelajaran Daring di Masa Pandemi Covid-19. IQ (Ilmu AlQur'an): Jurnal Pendidikan Islam, 3(01), 123-140. https://doi.org/10.37542/iq.v3i01.57

Denny, D. (2020). MOTIVASI TERHADAP KULIAH DARING SELAMA MASA PANDEMI CORONA VIRUS DISEASE (COVID-19) PADA MAHASISWA STMB MULTI SMART MEDAN. Jurnal Ilmiah SMART, 4(2), 107-117. http://stmbmultismart.ac.id/ejournal/index.php/JM BA/article/view/68

de Jong, P. G. (2020). Impact of Moving to Online Learning on the Way Educators Teach. Medical Science Educator, 30(3), 1003-1004. https://doi.org/10.1007/s40670-02001027-7

Desriva, N., Utari, M. D., \& Al Padri, A. (2020). EFEKTIVITAS METODE PEMBELAJARAN DARING TERHADAP MOTIVASI BELAJAR MAHASISWA SAAT PANDEMI $\begin{array}{llll}\text { COVID } & 19 & \text { DI } & \text { KOTA }\end{array}$ PEKANBARU. Ensiklopedia of Journal, 2(5), 124-130. http://jurnal.ensiklopediaku.org/ojs- 
Prisilia Tehupuring , Adriyanto J. Gundo

Hubungan Persepsi terhadap Metode Pembelajaran Daring dengan Motivasi Belajar Mahasiswa Program Studi Sistem Informasi-UKSW

Prima Magistra: Jurnal Ilmiah Kependidikan Volume 3, Nomor 1, Januari 2022, hal 71-84

2.4.8-

3/index.php/ensiklopedia/article/view/5 77

Dewi, L. (2021). Hubungan Persepsi terhadap Metode Pembelajaran Daring dengan Motivasi Belajar Mahasiswa Fakultas Kedokteran Universitas Sumatera Utara Selama Pandemi Covid-19. In Repositori Institusi Universitas Sumatera Utara. http://repositori.usu.ac.id/handle/12345 $6789 / 31059$

Firman, F., \& Rahman, S. R. (2020). Pembelajaran Online di Tengah Pandemi Covid-19. Indonesian Journal of Educational Science (IJES), 2(2), 81-89.

https://doi.org/10.31605/ijes.v2i2.659

Handarini, O. I., \& Wulandari, S. S. (2020). Pembelajaran Daring Sebagai Upaya Study From Home (SFH) Selama Pandemi Covid-19. Jurnal Pendidikan Administrasi Perkantoran (JPAP), 8(3). https://journal.unesa.ac.id/index.php/jpa p/article/view/8503

Harandi, S. R. (2015). Effects of e-learning on Students' Motivation. Procedia - Social and Behavioral Sciences, 181, 423430.

https://doi.org/10.1016/j.sbspro.2015.04 905

Hasanah, A., Sri, L. A., Rahman, A. Y., \& Danil, Y. I. (2020). Analisis Aktivitas Belajar Daring Mahasiswa Pada Pandemi COVID-19. Karya Tulis Ilmiah (KTI) Masa Work From Home (WFH) Covid-19 UIN Sunan Gunung Djati Bandung Tahun 2020, 4-8. http://digilib.uinsgd.ac.id/id/eprint/3056 5

Iskandar, I., Masthura, S., \& Oktaviyana, C. (2020). Penerapan Sistem Pembelajaran Daring Pada Mahasiswa Keperawatan Universitas Abulyatama. Jurnal Dedikasi Pendidikan, 4(2), 323-332. http://jurnal.abulyatama.ac.id/index.php /dedikasi/article/view/1058

Juliawan, I. W. (2020). PERSEPSI MAHASISWA BIMBINGAN
KONSELING

MAHADEWA

TERHADAP

UNIVERSITAS

DARING SEBAGAI SARANA

PEMBELAJARAN SELAMA MASA

PANDEMI COVID-19. Widyadari:

Jurnal Pendidikan, 21(2), 569-577.

https://doi.org/10.5281/zenodo.4048981

Kemendikbud (2020). Panduan: Pembelajaran Jarak Jauh. Tersedia di https://bersamahadapikorona.kemdikbu d.go.idKusuma, D. W. C. W., Muliadi, A., \& Imran, F. (2021). Pembelajaran Daring di Masa Pandemi Covid-19: Persepsi Mahasiswa Berbasis Gender. Jurnal Ilmiah Mandala Education, 7(3), 663-669.

https://doi.org/10.36312/jime.v7i3.2340

Marthika, L. (2020). ANALISIS MENTAL MAHASISWA BARU SAAT PEMBELAJARAN ONLINE ERA COVID-19 (Mahasiswa Baru Progam Studi Akuntansi Fakultas Ekonomi Universitas Muara Bungo Angkatan 2020). Jurnal Inovasi Penelitian, 1(8), 1527-1534.

https://doi.org/10.47492/jip.v1i8.321

Maulah, S., \& Ummah, N. R. (2020). Persepsi Mahasiswa Biologi terhadap Perkuliahan Daring Sebagai Sarana Pembelajaran Selama Pandemi Covid 19. ALVEOLI: Jurnal Pendidikan Biologi, 1(2), 49-61. https://doi.org/10.35719/alveoli.v1i2.6

Meece, J. L., Glienke, B. B., \& Burg, S. (2006). Gender and motivation. Journal of school psychology, 44(5), 351-373. https://doi.org/10.1016/j.jsp.2006.04.00 4

Megawanti, P., Megawati, E., \& Nurkhafifah, S. (2020). Persepsi Peserta Didik terhadap PJJ pada Masa Pandemi COVID-19. Jurnal Ilmiah Pendidikan, $7(2)$, 75-82. https://journal.lppmunindra.ac.id/index. php/Faktor/article/view/6411

Muhali, M. (2019). Pembelajaran Inovatif Abad Ke-21. Jurnal Penelitian dan Pengkajian Ilmu Pendidikan: $e$ Saintika, 3(2),

25-50. 
Prisilia Tehupuring , Adriyanto J. Gundo

Hubungan Persepsi terhadap Metode Pembelajaran Daring dengan Motivasi Belajar Mahasiswa Program Studi Sistem Informasi-UKSW

Prima Magistra: Jurnal Ilmiah Kependidikan Volume 3, Nomor 1, Januari 2022, hal 71-84

https://doi.org/10.36312/e-

saintika.v3i2.126

Muhammad, I. (2020). Pengaruh Perkuliahan Daring Terhadap Kemandirian Belajar Mahasiswa Prodi Pendidikan Matematika Universitas Malikussaleh. Jurnal Ilmiah Pendidikan Matematika Al Qalasadi, 4(1), 24-30. https://doi.org/10.32505/qalasadi.v4i1.1 567

NurCita, B., \& Susantiningsih, T. S. (2020). DAMPAK PEMBELAJARAN JARAK JAUH DAN PHYSICAL DISTANCING PADA TINGKAT KECEMASAN

MAHASISWA. Journal of Borneo Holistic Health, 3(1). https://doi.org/10.35334/borticalth.v3i1. 1389

Nursalam, N. (2008). Konsep dan Penerapan Metodologi Penelitian Ilmu Keperawatan. Jakarta: Salemba Medika. Google Scholar

Paais, R. L., \& Andreas. (2021). Penerapan TIK Melalaui Penggunaan LMS Google Classroom, Google Meet dan WhatsApp Pada Pembelajaran di Masa Pandemi Covid-19. Prosiding Webinar Nasional IAHN-TP Palangka Raya, 6, 134-150.

https://prosiding.iahntp.ac.id/index.php/ seminar-nasional/article/view/173

Radovan, M., \& Makovec, D. (2015). Adult Learners' Learning Environment Perceptions and Satisfaction in Formal Education-Case Study of Four EastEuropean Countries. International Education Studies, 8(2), 101-112. https://doi.org/10.5539/ies.v8n2p101

Rahmaniati, R., \& Bulkani, B. (2020). Perbedaan Persepsi Mahasiswa tentang Perkuliahan Daring. Anterior Jurnal, 20(1), $28-33$. https://doi.org/10.33084/anterior.v20i1. 1610

Raza, S. A., Qazi, W., Khan, K. A., \& Salam, J. (2021). Social Isolation and Acceptance of the Learning Management System (LMS) in the time of COVID-19 Pandemic: An Expansion of the UTAUT Model. Journal of Educational Computing Research, 59(2), 183-208. https://doi.org/10.1177/0735633120960 421

Rovai, A., Ponton, M., Wighting, M., \& Baker, J. (2007). A comparative analysis of student motivation in traditional classroom and e-learning courses. International Journal on Elearning, 6(3),

413-432. https://www.learntechlib.org/primary/p/ 20022

Rücker, J. C. (2012). The relationship between motivation, perceived stress and academic achievement in students (Bachelor's thesis, University of Twente). http://purl.utwente.nl/essays/62412

Setyawan, A. (2016). Apakah Gender Bermakna Pada Model Pembentukan Minat Berwirausaha? Jurnal Manajemen Teori Dan Terapan| Journal of Theory and Applied Management, 9(2), 120-127. https://doi.org/10.20473/jmtt.v9i2.3017

Simatupang, N. I., Sitohang, S. R. I., Situmorang, A. P., \& Simatupang, I. M. (2020). Efektivitas pelaksanaan pengajaran online pada masa pandemi covid-19 dengan metode survey sederhana. Jurnal Dinamika Pendidikan, 13(2), 197-203. http://ejournal.uki.ac.id/index.php/jdp/a rticle/view/1754

Song, L., Singleton, E. S., Hill, J. R., \& Koh, M. H. (2004). Improving online learning: Student perceptions of useful and challenging characteristics. The internet and higher education, 7(1), 5970.

https://doi.org/10.1016/j.iheduc.2003.1 1.003

Sriharan, A. (2020). Teaching Online: Tips for Engaging Students in Virtual Classrooms. Medical Science Educator, 30(4), 1673-1675. https://doi.org/10.1007/s40670-02001116-7 
Prisilia Tehupuring , Adriyanto J. Gundo

Hubungan Persepsi terhadap Metode Pembelajaran Daring dengan Motivasi Belajar Mahasiswa Program Studi Sistem Informasi-UKSW

Prima Magistra: Jurnal Ilmiah Kependidikan Volume 3, Nomor 1, Januari 2022, hal 71-84

Suharto, E. (2009). Membangun Masyarakat Memberdayakan Rakyat, Bandung: PT. Refika Aditama. Google Scholar

Sugiyono, S. (2007). Memahami Penelitian Kualitatif. Bandung: CV. Alfabeta. Google Scholar.

Sur, W. A. A., Hasanah, M., \& Mustofa, M. R. (2020). Analisis Motivasi Belajar Mahasiswa dengan Sistem Pembelajaran Daring Selama Masa Pandemi Covid-19. Jurnal Equation: Teori dan Penelitian Pendidikan Matematika, 3(2), 157-171. https://ejournal.iainbengkulu.ac.id/inde x.php/equation/article/view/3464

Suryana, Y., Sanusi, H. P., Hermawan, A. H., \& Hidayat, W. (2020). Manajemen Pembelajaran Daring Berbasis Empati untuk Pemeliharaan Motivasi Belajar Daring Mahasiswa dalam Situasi Wabah COVID-19. Digital Library, UIN SUnan Gung Djati, Bandung, 114.

http://digilib.uinsgd.ac.id/id/eprint/3069 8
Tantri, N. R. (2018). Kehadiran sosial dalam pembelajaran daring berdasarkan sudut pandang pembelajar pendidikan terbuka dan jarak jauh. Jurnal Pendidikan Terbuka Dan Jarak Jauh, 19(1), 19-30. https://doi.org/10.33830/ptjj.v19i1.310. 2018

Wibowo, N. (2016). Upaya peningkatan keaktifan siswa melalui pembelajaran berdasarkan gaya belajar di SMK Negeri 1 Saptosari. Elinvo (Electronics, Informatics, and Vocational Education), 1(2), 128-139. https://doi.org/10.21831/elinvo.v1i2.10 621

Yaumi, M. (2018). Media Dan Teknologi Pembelajaran. Jakarta: Prenadamedia Group. Google Scholar

Zhafira, N. H., Ertika, Y., \& Chairiyaton, C. (2020). Persepsi mahasiswa terhadap perkuliahan daring sebagai sarana pembelajaran. Jurnal Bisnis Dan Kajian Strategi Manajemen, 4(1). http://jurnal.utu.ac.id/jbkan/article/view $/ 1981$ 
Prisilia Tehupuring , Adriyanto J. Gundo

Hubungan Persepsi terhadap Metode Pembelajaran Daring dengan Motivasi Belajar Mahasiswa Program Studi Sistem Informasi-UKSW

Prima Magistra: Jurnal Ilmiah Kependidikan Volume 3, Nomor 1, Januari 2022, hal 71-84 